\title{
Paulina KURZYK*
}

\section{ZMIANY DOSTĘPNOŚCI PIESZEJ I ROWEREM KLUCZOWYCH PRZESTRZENI PUBLICZNYCH W UNIEJOWIE NA PRZYKLADZIE KLADKI PIESZEJ NA WARCIE}

\begin{abstract}
Zarys treści: Celem artykułu jest ocena zmian dostępności pieszej i rowerem, kluczowych przestrzeni publicznych w Uniejowie, na przykładzie kładki pieszej na Warcie. Przestrzenie publiczne, to miejsca pełniące szereg funkcji zarówno w sferze ekonomicznej, jak i społecznej. Ich szczególną cechą jest dostępność, która będzie stanowiła przedmiot rozważań niniejszego opracowania. W pracy posłużono się metodą izochron, aby ukazać zmiany powierzchni zabudowy jedno- i wielorodzinnej, w przyjętych przedziałach czasowych. Wykazuje ona jak ważnym elementem w kształtowaniu dostępności, dla użytkowników przestrzeni publicznych, może być kładka piesza.
\end{abstract}

Słowa kluczowe: dostępność piesza, kładka piesza, dostępność rowerem, kluczowa przestrzeń publiczna, Uniejów

\section{ROLA DOSTĘPNOŚCI W PRAWIDŁOWYM FUNKCJONOWANIU PRZESTRZENI PUBLICZNYCH}

Zgodnie z Ustawa z dnia 27 marca 2003 r. o planowaniu i zagospodarowaniu przestrzennym przestrzeń publiczna to „obszar o szczególnym znaczeniu dla zaspokojenia potrzeb mieszkańców, poprawy jakości ich życia i sprzyjający nawiązywaniu kontaktów społecznych ze względu na jego położenie oraz cechy funkcjonalno-przestrzenne, określony w Studium uwarunkowań i kierunków zago-

* Paulina Kurzyk, mgr, asystent, Uniwersytet Łódzki, Wydział Nauk Geograficznych, Instytut Zagospodarowania Środowiska i Polityki Przestrzennej, ul. Kopcińskiego 31, 90-142 Łódź, e-mail: paulina.kurzyk@geo.uni.lodz.pl 
spodarowania przestrzennego gminy ${ }^{1}$. Zapis ten definiuje zatem przestrzeń publiczną wielowymiarowo. Jest to obszar, który łączy w sobie zarówno cechy społeczne, jak i ekonomiczne. W literaturze przedmiotu, która bogata jest w definicje takich obszarów, zwraca się uwagę na ich nieograniczony dostęp. Według S. Nissena $(2008)^{2}$, przestrzeń publiczna jest zasadniczo otwarta publicznie i nie posiada ograniczeń $\mathrm{w}$ korzystaniu. Warto przytoczyć $\mathrm{w}$ tym miejscu również podejście reprezentowane przez P. Lorensa $(2010)^{3}$, który w znaczącym stopniu kładzie nacisk na aspekt ogólnodostępności tych przestrzeni, które ponadto mają stanowić fizyczną platformę interakcji społecznych. T. Ossowicz (2009) ${ }^{4}$ twierdzi, że przestrzeń publiczna powinna dodatkowo charakteryzować się dobrą dostępnością oraz funkcjonalnością przy zachowaniu poczucia bezpieczeństwa i atrakcyjności urbanistycznej obszaru. Natomiast według J. Chmielewskiego $(2005)^{5}$ przestrzenie publiczne to przede wszystkim ulice, ciągi piesze, parki, skwery czy place miejskie. Zdaniem A. Rochmińskiej (2014) przestrzeń publiczna posiada trzy przymioty: własność, dostępność oraz intersubiektywność. Pierwszy z nich odnosi się do sposobu władania, który wedle tradycyjnego ujęcia dzieli przestrzenie publiczne na własność państwową lub samorządową, przez to dostępną dla każdego bez ograniczeń i sprzyjając tym samym rozwojowi więzi społecznych ${ }^{6}$. Stąd też jedną z cech fizjonomicznych przestrzeni publicznych jest dostępność, którą rozważać można pod względem komunikacyjnym oraz psychologicznym. Drugi aspekt wiąże się ściśle z fizjonomią miejsca, jego otwartością, czytelnością czy nawet $\mathrm{z}$ widocznością․ $\mathrm{W}$ artykule przyjęto, że przestrzenie publiczne to miejsca, które pełnią szereg funkcji, mają m.in. zaspokoić potrzeby mieszkańców oraz służyć poprawie jakości życia. Dodatkowo są one platformą interakcji społecznych, a także ważnym miejscem spędzania wolnego czasu. Dlatego też niezwykle ważny jest poziom ich dostępności, który decyduje nie tylko o ich atrakcyjności, ale i możliwościach rozwojowych, natomiast za kluczowe uznano te obszary charakteryzujące się mnogością funkcji turystycz-

1 Ustawa z dnia 27 marca 2003 r. o planowaniu $i$ zagospodarowaniu przestrzennym (DzU 2003, poz. 717), art. 2, pkt 6.

2 S. Nissen, Urban Transformation from Public and Private Space to Space of Hybrid Character, „Czech Sociological Review” 2008, t. 44, nr 6, s. 1129-1149.

3 P. Lorens, Definiowanie wspótczesnej przestrzeni publicznej, [w:] P. Lorens, J. Martyniuk-Pęczek (red.), Problemy ksztaltowania przestrzeni publicznych, „Urbanista” 2010, s. 10.

4 T. Ossowicz, Przestrzenie publiczne w sferze dyskusji, Konferencja naukowa na temat przestrzeni publicznej, Poznań, 27-29.05.2009.

5 J.M. Chmielewski, Przestrzeń publiczna w teorii urbanistyki, [w:] S. Gzell (red.), Przestrzeń publiczna jako element krystalizacji zespołów urbanistycznych, „Urbanistyka. Międzyuczelniane Zeszyty Naukowe" 2005, s. 5-10.

6 A. Rochmińska, Centra handlowe jako przestrzenie hybrydowe, „Space-Society-Economy" 2014, nr 13, s. 281-297.

7 D. Soszyński, B. Sowińska-Świerkosz, A. Gawryluk, Kształtowanie wiejskich przestrzeni publicznych - ocena rozwiazań krajobrazowych w wybranych gminach Polesia Zachodniego, „Prace Komisji Krajobrazu Kulturowego” 2016, nr 34, s. 150. 
nych, gospodarczych a także te, które związane są z historycznym kształtowaniem przestrzeni miejskiej.

W niniejszej pracy skupiono się na aspekcie dostępności przestrzeni publicznej, dlatego też konieczne jest jej zdefiniowanie. Ujmując najogólniej, dostępność to zdolność zajścia relacji między więcej niż jednym elementem danego zbioru. Posiada ona swoje trzy zasadnicze własności - przestrzenne, komunikacyjne i czasowe. Pierwsza z nich dotyczy zależności, jakie mogą zachodzić pomiędzy co najmniej dwoma punktami, czyli w przestrzeni. Aspekt komunikacyjny należy odnieść z kolei do relacji, które zachodzić mogą przy wykorzystaniu środków transportowych. Ostatnia właściwość odnosi się do czasu, relacje mogą zachodzić w danym czasie fizycznym, ale również nawiązanie relacji, np. w postaci przemieszczenia, zajmuje określoną ilość czasu9 . Należy podkreślić, że zjawisko dostępności ma charakter potencjalny, a więc relacja może zajść na danym terenie przy użyciu konkretnych środków transportu w wyznaczonym czasie ${ }^{10}$. W literaturze przedmiotu wyróżnia się kilka rodzajów dostępności, m.in. przestrzenną, czasową, komunikacyjną, społeczną czy transportową. Tym samym istnieje szereg możliwości jej mierzenia, m.in. wyposażeniem infrastrukturalnym, odległością, izochronami, maksymalizacją użyteczności ${ }^{11}$. Według M. Borowskiej-Stefańskiej i M. Wojtczak (2019) ${ }^{12}$, dostępność uznaje się za kluczowy element przestrzeni, która wpływa na atrakcyjność danej lokalizacji. Dlatego też, konfrontując ze sobą powyższe podejścia i definicje, dotyczące zarówno opisywanych obszarów miejskich, jak i dostępności, należy domniemywać, że faktyczne funkcjonowanie przestrzeni publicznych, a także ich atrakcyjność wynika z poziomu dostępności.

Znając wyznaczniki „,idealnych” przestrzeni publicznych, trzeba zdawać sobie sprawę z ograniczeń i przeszkód, jakie powstają w trakcie ich rozwoju. W pierwszej kolejności powinno się wskazać bariery przestrzenne, które należy łączyć z utrudnionym poruszaniem się po danej przestrzeni publicznej. Do barier przestrzennych zaliczyć można także m.in. chaotyczną lokalizację budynków małej architektury czy wąskie przejścia, szczególnie tam, gdzie występuje duże natężenie parkowania.

Kolejna grupa to bariery wynikające z sytuacji społeczno-ekonomicznej, związane z płatnym lub niepłatnym przebywaniem $\mathrm{w}$ danej przestrzeni publicznej. Ponadto utrudnienia w rozwoju przestrzeni publicznych mogą mieć aspekt psycho-

8 T. Komornicki i in., Dostępność przestrzenna jako przesłanka ksztaltowania polskiej polityki transportowej, „Biuletyn KPZK PAN” 2010, z. 241, s. 16.

9 M. Borowska-Stefańska, M. Wojtczak, Dostęność piesza i transportem indywidualnym..., s. 162.

${ }^{10}$ P. Śleszyński, Dostępność czasowa i jej zastosowania, „Przegląd Geograficzny” 2014, nr 86 (2), s. 173.

${ }^{11}$ G. Sierpiński, Miary dostepności transportowej miast i regionów, „Zeszyty Naukowe Politechniki Śląskiej. Transport” 2010, z. 66, s. 91.

${ }^{12}$ M. Borowska-Stefańska, M. Wojtczak, Dostęnność piesza i transportem indywidualnym..., s. 162. 
logiczny, który nierozerwalnie wiąże się z poczuciem bezpieczeństwa. Ta grupa barier może z kolei wiązać się $\mathrm{z}$ negatywnym postrzeganiem danej przestrzeni w związku z jej agresywnymi użytkownikami, którzy oddziałują na nią nie tylko poprzez fizyczną obecność, ale i różnego rodzaju wandalizm ${ }^{13}$.

W przypadku analizowanego obszaru barierą, która decyduje o dostępności wskazanych przestrzeni publicznych, jest rzeka Warta, a więc ,przeszkoda” naturalna. Poprzez swoją fizjonomię stanowi ona swego rodzaju „rozcięcie” wcześniej wspomnianych węzłów tworzących kluczowa przestrzeń publiczna miasta, a tym samym wpływa na dostępność poszczególnych przestrzeni. Rozwiązaniem, które pozwala na połączenie obszaru Starego Rynku z termami i kompleksem zamkowo-parkowym, jest kładka piesza, stanowiąca tym samym stanowi jeden z elementów kształtowania dostępności kluczowych przestrzeni publicznych w Uniejowie. Głównym celem pracy jest zatem ocena zmian dostępności pieszej i rowerem kluczowych przestrzeni publicznych w Uniejowie na przykładzie funkcjonowania kładki pieszej nad Wartą. W artykule pokazano jak istotnym elementem zagospodarowania przestrzeni w Uniejowie jest wyżej wspomniany obiekt mostowy, który może decydować o wyborze miejsc odwiedzanych przez ludzi. W pracy zwrócono uwagę na mnogość funkcji, jakimi może wykazać się taka budowla, począwszy od poprawy dostępności łączących się przestrzeni, po kształtowanie nowego ładu architektonicznego oraz środowiskowego różnego rodzaju przestrzeni.

\section{KŁADKI PIESZE JAKO ELEMENT KSZTAŁTOWANIA PRZESTRZENI - PRZYKŁADY}

Kładka, zgodnie z Ustawa z dnia 21 marca 1985 roku o drogach publicznych, zaliczana jest do budowli mostowych, a więc obiektów przeznaczonych do przeprowadzania drogi, samodzielnego ciągu pieszego, pieszo-rowerowego, szlaku wędrówek zwierząt dziko żyjących lub innego rodzaju komunikacji gospodarczej nad przeszkodą terenową. Obok kładek do konstrukcji tego typu zalicza się wiadukty czy estakady ${ }^{14}$. Obiekty te są zatem niezbędnym elementem zagospodarowania miast na obszarach, gdzie występują cieki, zapewniając komunikację pieszą lub pieszo-rowerową. Przytoczona definicja pozwala na stwierdzenie, że obiekty te zapewniają łączność między dwoma odległymi punktami, do których dostęp utrudniony jest przez pewną przeszkodę. Ponadto takie rozwiązanie umożliwia ruchu

${ }^{13}$ D. Brodowicz, A. Domaradzka, K. Sadowy, Lokalność, przestrzeń publiczna, kapitat spoteczny - cele, osiagnięcia $i$ wyzwania ksztaltowania przestrzeni publicznej Warszawy w odniesieniu do Spotecznej Strategii Warszawy oraz propozycje metodologii monitorowania jej realizacji, „Raport” 2015, s. 22-23.

${ }^{14}$ Ustawa z dnia 21 marca 1985 r. o drogach publicznych (DzU 1985, poz. 60), art. 4, pkt 13. 
pieszego, który jest podstawą przemieszczania ludności miejskiej ${ }^{15}$. W przypadku Uniejowa i jego kluczowych przestrzeni publicznych kładka pozwala na pokonywanie bariery, jaką jest Warta.

Tego typu rozwiązanie techniczne to nieodzowny element kształtowania struktury miejskiej, a literatura bogata jest w przykłady pokazujące zastosowanie takiej budowli. Poza poprawą dostępności wzbogaca ona walory estetyczne określonych miejsc oraz zapewnia bezpieczne przemieszczanie się. Egzemplifikacją takiego rozwiązania jest niewątpliwie kładka „Bernatka” na Wiśle, która połączyła Stare Miasto z Podgórzem w Krakowie. Oddana do użytku w 2010 roku wpłynęła na zmianę struktury funkcjonalno-przestrzennej śródmieścia. Na trwałe wpisała się ona w urbanistyczną tkankę dawnego grodu Piastów. Dodatkowo, oprócz spełniania funkcji komunikacyjnej, stała się nowym symbolem tej części miasta, a tym samym ukształtowała nową tożsamość miejsca ${ }^{16}$. Według A. Sargi (2014), autorki badań dotyczących omawianego obiektu, poprawa dostępności terenów, które połączyła „Bernatka”, przyczyniła się do rozwoju funkcji kulturalnych, a także ożywienia turystycznego w tych obszarach ${ }^{17}$.

Budowa kładek bogatych w walory estetyczne i architektoniczne prowadzi do powstania niezwykle oryginalnych obiektów mostowych. Przykładem takiej konstrukcji jest łukowa kładka dla pieszych przez rzekę Wartę we Wronkach (woj. wielkopolskie) ${ }^{18}$. W tym przypadku nowatorstwo tego obiektu opiera się na zastosowaniu konstrukcji złożonej z przęseł łukowatych - czyli najnowszych trendów architektonicznych. Obiekt ten połączył północną część miasta z jego historycznym centrum, tym samym radykalnie zmieniając układ komunikacyjny ${ }^{19}$ i ułatwiając mieszkańcom poruszanie się.

Jak wcześniej wspomniano, analizowane obiekty oddziałują na percepcję przestrzeni podczas przemieszczania się, zatem budowa kładki powinna być przemyślana i w miarę możliwości wpasować się w otaczający ją krajobraz. Rozwiązaniem tego typu, w którym zwrócono szczególną uwagę na zachowanie spójności między konstrukcją techniczną a środowiskiem, jest kładka na rzece Rabie, łącząca Krzyżanowice z Proszówkami (woj. małopolskie). Konstrukcja ta nie zakłóca walorów przyrodniczych, a zarazem odwołuje się do rodzimego budownictwa ludowego ${ }^{20}$.

${ }^{15}$ M. Dębowska-Mróz, P. Lis, Ksztaltowanie przestrzeni transportowej dedykowanej pieszym i rowerzystom jako element poprawy mobilności w miastach, „Autobusy: Technika, Eksploatacja, Systemy Transportowe” 2017, nr 18, s. 523.

16 A. Sarga, Wptyw kładki „Bernatka” na strukture funkcjonalno-przestrzenna krakowskiego Kazimierza i Podgórza, „Przestrzeń i Forma” 2014, nr 21, s. 473-482.

17 Tamże, s. 480-481.

${ }^{18}$ K. Żółtowski, M. Binczyk, T. Galewski, Łukowa kładka dla pieszych przez rzekę Warta we Wronkach: projekt i realizacja, „Mosty” 2015, s. 54-56.

19 Tamże, s. 54.

${ }^{20}$ M. Furtak, Remont i częściowa odbudowa kładki pieszej przez rzekę Rabę, w perspektywie krajobrazowo-kulturowo-inżynierskiej, „Przestrzeń i Forma” 2011, nr 16, s. 577-588. 
Przesłanki do powstania kładki pieszej w Uniejowie były niemal identyczne jak w przypadku wyżej opisanych. Przede wszystkim jej głównym zadaniem było skrócenie drogi do pobliskiego zamku i połączenie go z obszarem miasta. Początki teraźniejszego obiektu sięgają lat 50 . XX wieku, kiedy to na obszarze miasta wybudowano most na Warcie, który odciążył ruch kołowy i spełniał funkcje tranzytowe. Wtedy też doszło do protestów mieszkańców, którzy byli niezadowoleni z powodu znaczącego wydłużenia się szlaku pieszego. Nową kładkę oddano do użytku w 1971 roku, zastąpiła starą, drewnianą budowlę ${ }^{21}$. Konstrukcja ta stała się jedną $\mathrm{z}$ atrakcji turystycznych miasta, ponieważ stanowi ona doskonałe miejsce do podziwiania zamku oraz doliny rzecznej. Ponadto ustawiono przy niej tablicę z informacjami dotyczącymi nadania miastu statusu uzdrowiska. Jej łączna długość to niemal $80 \mathrm{~m}^{22}$. Na przestrzeni lat stan techniczny oraz estetyczny tego obiektu znacząco się pogorszył, dlatego też władze miejskie zdecydowały się na jego remont, który przewidziano na lata 2019-2020. Inwestycja realizowana jest w ramach pierwszego etapu projektu „Budowa infrastruktury turystycznej oraz zagospodarowanie terenu wzdłuż rzeki Warty w Uniejowie", który jest współfinansowany ze środków unijnych w ramach Europejskiego Funduszu Rozwoju Regionalnego ${ }^{23}$.

\section{CHARAKTERYSTYKA OBSZARU BADAŃ I METODOLOGIA}

Zgodnie z dokumentem pt. Zmiana studium uwarunkowań i kierunków zagospodarowania przestrzennego gminy i miasta Uniejó $w^{24}$ na badanym obszarze jako przestrzenie publiczne wskazano następujące miejsca: zespół zamkowo-parkowy, tereny leżące na lewym brzegu rzeki Warty rozciągające się od mostu do kładki, rynek ze skwerem przy kościele Najświętszej Maryi Panny, skwery będące jednocześnie zielenią miejską wokół kościołów św. Mikołaja i Bożego Ciała, a także wszystkie cmentarze. Według A. Wojnarowskiej $(2015)^{25}$ na terenie Uniejowa wydzielić można trzy węzły, które wraz z osiami tworzą kluczowa przestrzeń publiczna, będącą widoczną reperkusją historycznego kształtowania się miasta, które rozwijało się po obu brzegach Warty.

Węzeł A, czyli Stary Rynek, znajdujący się na prawym brzegu rzeki, który jednocześnie związany jest z najstarszą fazą rozwoju Uniejowa. To najbardziej złożona pod względem funkcjonalnym przestrzeń analizowanego miasta. Ponadto,

${ }^{21}$ A. Wojnarowska, Przestrzeń publiczna Uniejowa, „Biuletyn Uniejowski” 2015, t. 4, s. 38.

${ }^{22}$ Pomiar na podstawie http://www.geoportal.gov.pl [dostęp: 4.05.2020].

${ }^{23} \mathrm{https} / / /$ mapadotacji.gov.pl/projekty/756630/ [dostęp: 4.05.2020].

${ }^{24}$ Zmiana studium uwarunkowań i kierunków zagospodarowania przestrzennego gminy i miasta Uniejów, Uniejów 2007-2009, s. 104-105.

${ }^{25}$ A. Wojnarowska, Przestrzeń publiczna .... s. 42. 
co ważne, ,potencjał zlokalizowanych tam funkcji stanowi o jego atrakcyjności i w dużym stopniu warunkuje przyciąganie ludzi do przestrzeni miejskiej"26. Węzeł B - zespół zamkowo-parkowy położony na lewym brzegu Warty, którego rozwój łączyć należy z latami 60. XX w. i rewaloryzacją oraz upublicznieniem kompleksu zamkowego. Powstanie ostatniego węzła C - strefy uzdrowiskowo-rekreacyjnej (ryc. 1), należy natomiast konsolidować z uzyskaniem przez miasto statusu uzdrowiska ${ }^{27}$. Przypatrując się ich rozlokowaniu w strukturze przestrzenno-funkcjonalniej miasta, kluczowa wydaje się być kładka piesza, która jest elementem łączącym, a jednocześnie wpływającym na dostępność (pieszą i rowerową) tych przestrzeni. W przypadku Uniejowa, który położony jest na prawym brzegu Warty, na wysokiej skarpie, to właśnie rzeka odgrywała i nadal odgrywa istotną rolę w kształtowaniu planu miasta ${ }^{28}$.

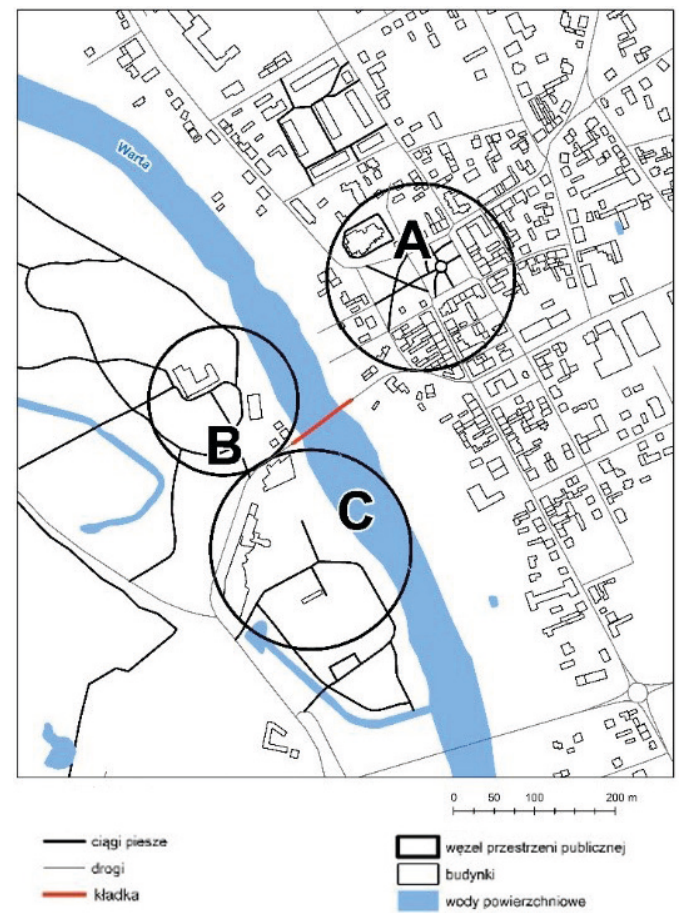

Ryc. 1. Kluczowa przestrzeń publiczna w Uniejowie:

A. Stary Rynek, B. Zamek Arcybiskupów Gnieźnieńskich, C. Termy Uniejów

Źródło: opracowanie własne na podstawie A. Wojnarowska, Przestrzeń publiczna ..., s. 41

${ }^{26}$ M. Lamprecht, Kilka uwag o rozwoju Uniejowa $w$ świetle nowych funkcji miasta, ,Biuletyn Uniejowski” 2012, t. 1, s. 132.

27 A. Wojnarowska, Przestrzeń publiczna ..., s. 42.

${ }^{28}$ M. Lamprecht, Kilka uwag o rozwoju Uniejowa..., s. 131-132. 
Badając dostępność, posłużono się izochronami, a więc metodą kumulatywną, która wyznacza obszary o jednakowej odległości czasowej ${ }^{29}$. W pracy dokonano analizy czasu dojścia pieszego i dojazdu rowerem do wskazanych przestrzeni publicznych. Przyjęto sześć możliwych przedziałów czasowych do: 5, 10, 15, 20, 25 i 30 min dojścia pieszego i dojazdu rowerem. W badaniach założono, że człowiek porusza się z średnią prędkością $4,8 \mathrm{~km} / \mathrm{h}$, natomiast w przypadku dojazdu rowerem za średnią uznano prędkość $15 \mathrm{~km} / \mathrm{h}^{30}$. W pracy wykorzystano zasoby OpenStreetMap (OSM), a więc bazy danych stworzonych przez Steve'a Costa. Informacje te mają stanowić otwartą mapę świata z możliwością edytowania przez wszystkich użytkowników ${ }^{31}$. Obliczeń dokonano przy użyciu analiz sieciowych w programie ArcMap. Ich wynikiem jest ukazanie powierzchni zabudowy jedno- i wielorodzinnej w wyznaczonych strefach. Informacje o zabudowie mieszkaniowej pochodzą z Bazy Danych Obiektów Topograficznych. Zmianę dostępności wyrażono natomiast poprzez różnicę powierzchni zabudowy mieszkaniowej (zarówno jedno-, jak i wielorodzinnej), w przypadku gdy na Warcie znajduje się kładka pieszo-rowerowa i bez niej.

\section{DOSTĘPNOŚĆ PIESZA}

Analizę, którą przeprowadzono, oparto na sześciu strefach dojścia pieszego w ciągu: 5, 10, 15, 20, 25 i 30 min do przestrzeni publicznych w Uniejowie. Badając zmiany dostępności, w pierwszej kolejności wzięto pod uwagę aktualną sytuację w mieście - przestrzenie publiczne połączone kładką, następnie sprawdzono, jak sytuacja wyglądałaby, gdyby na obszarze miasta nie wybudowano takiego obiektu.

\section{A. Stary Rynek}

Stary Rynek to przestrzeń położona na prawym brzegu Warty. Izochrony dojścia pieszego, w przypadku połączenia tego obszaru z pozostałymi przestrzeniami publicznymi kładką pieszą, zajmują łącznie 1126 ha, co stanowi 8,7\% powierzchni gminy Uniejów (ryc. 2). Łącznie w zasięgu wyznaczonych stref znajduje się 914 budynków mieszkalnych: 22 wielorodzinne i 892 jednorodzinne, które obejmują obszar 8,57 ha (tab. 1).

${ }^{29}$ S. Wiśniewski, Zróżnicowanie dostęności transportowej miast w województwie łódzkim, Wyd. Uniwersytetu Łódzkiego, Łódź 2015, s. 25.

${ }^{30}$ R. Rakower, J. Łabędzki, J. Gadziński, Konkurencyjność ruchu rowerowego w przestrzeni miejskiej, „Transport Miejski i Regionalny” 2011, nr 2, s. 32.

${ }^{31}$ M. Borowska-Stefańska, M. Wojtczak, Dostępność piesza i transportem indywidualnym do parków w Turku i Koninie, „Biuletyn Uniejowski” 2019, t. 8, s. 164. 
A

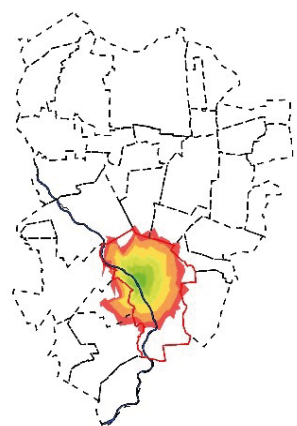

C

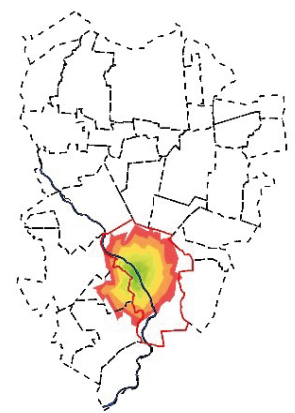

B

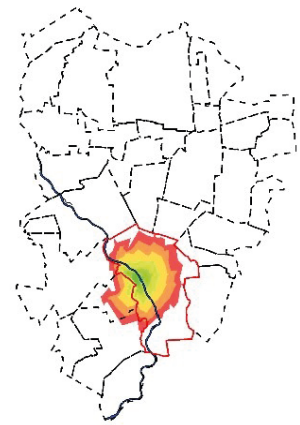

Ryc. 2. Czas dojścia pieszego [min] (przez kładkę pieszą) do:

A. Starego Rynku, B. zamku, C. term w Uniejowie Źródło: opracowanie własne na podstawie OSM

Wśród budynków jednorodzinnych najwięcej (32\% wszystkich budynków) znajduje się w zasięgu 5-10 minut dojścia do opisywanej przestrzeni publicznej, o łącznej powierzchni 2,34 ha, najmniej (4\% wszystkich budynków) natomiast jest ich w izochronie 25-30 minut. W przypadku budynków wielorodzinnych wszystkie znajdują się w trzech pierwszych przyjętych przedziałach czasowych, największy odsetek stanowią te zlokalizowane w najbliższej izochronie $0-5 \mathrm{~min}$ $-64 \%$ (0,39 ha) (tab. 1).

W wariancie bez kładki na Warcie powierzchnia izochron jest mniejsza i wynosi 1021 ha (ryc. 3). Liczba budynków jednorodzinnych zmniejsza się nieznacznie do 886, przy czym ich największa powierzchnia przypada również na izochronę 5-10 min, zajmując łącznie 2,35 ha (tab. 1). W zasięgu tych izochron zwiększyła się natomiast liczba budynków wielorodzinnych do 30. Największa ich liczba znajduje się w izochronie do 5 minut dojścia pieszego od Starego Rynku. W odniesieniu do lokalizacji Starego Rynku, przy wykorzystaniu kładki pieszej, zamek oraz termy znajdują się w odległości od 5 do 10 minut, natomiast gdyby jej nie było, droga ta wydłużyłaby się o ok. 10 minut dojścia pieszego. 


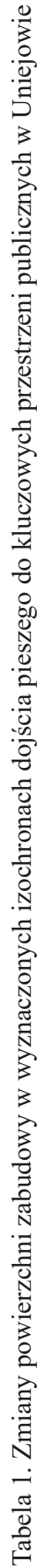

\begin{tabular}{|c|c|c|c|c|c|c|c|c|c|c|c|c|c|c|c|}
\hline \multirow{3}{*}{ 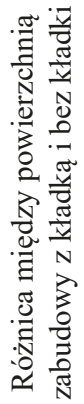 } & 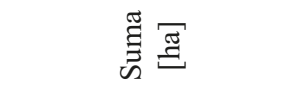 & $\begin{array}{l}\text { t } \\
0 \\
+\end{array}$ & 8 & $\begin{array}{l}8 \\
0\end{array}$ & $\begin{array}{l}0 \\
0 \\
i \\
i\end{array}$ & $\begin{array}{l}\overline{0} \\
0 \\
1\end{array}$ & $\begin{array}{l}\infty \\
0 \\
0 \\
+\end{array}$ & $\begin{array}{l}8 \\
0 \\
0 \\
+\end{array}$ & $\begin{array}{l}n \\
0 \\
0 \\
+\end{array} \mid$ & $\begin{array}{l}n \\
\tilde{m} \\
+ \\
+\end{array}$ & $\begin{array}{l}0 \\
\stackrel{-}{+} \\
+\end{array}$ & $\begin{array}{l}n \\
2 \\
0 \\
+\end{array}$ & $\stackrel{n}{\because}$ &  & $\begin{array}{l}0 \\
\stackrel{0}{+} \\
+\end{array}$ \\
\hline & 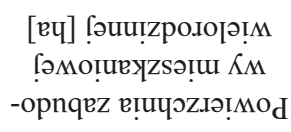 & \&. & 8 & $\begin{array}{l}8 \\
8 \\
0\end{array}$ & 8 & $\begin{array}{l}8 \\
0 \\
0\end{array}$ & \&. & $\begin{array}{l}8 \\
8 \\
0\end{array}$ & $\begin{array}{l}8 \\
0 \\
0\end{array}$ & $\left|\begin{array}{l}n \\
2 \\
0 \\
+ \\
+\end{array}\right|$ & $\begin{array}{l} \pm \\
\overrightarrow{0} \\
+\end{array}$ & $\begin{array}{l}- \\
\overline{0} \\
+\end{array}$ & $\mid \begin{array}{l}0 \\
2 \\
0 \\
1 \\
1\end{array}$ & $\frac{m}{0}$ & $\begin{array}{l}\text { I } \\
\\
+\end{array}$ \\
\hline & 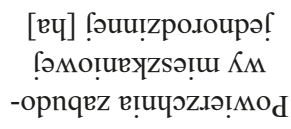 & $\begin{array}{l}\text { T. } \\
0 \\
1\end{array}$ & 8 & $\begin{array}{l}8 \\
0\end{array}$ & $\begin{array}{l}0 \\
0 \\
0 \\
0\end{array}$ & $\begin{array}{l}\overrightarrow{0} \\
0 \\
1\end{array}$ & $\left|\begin{array}{l}\infty \\
0 \\
0 \\
+\end{array}\right|$ & $\begin{array}{l}0 \\
0 \\
0 \\
+\end{array}$ & $\left|\begin{array}{l}n \\
0 \\
0 \\
+\end{array}\right|$ & $\begin{array}{l}8 \\
8 \\
i \\
+\end{array}$ & $\begin{array}{l}3 \\
\hat{i} \\
\text { i }\end{array}$ & $\left|\begin{array}{l}2 \\
0 \\
0 \\
0\end{array}\right|$ & $\begin{array}{l}2 \\
\hat{0} \\
+ \\
+\end{array}$ & $\stackrel{m}{m}$ & $\frac{\hat{\sigma}}{\mp}$ \\
\hline \multirow{3}{*}{ 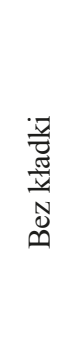 } & 駡 & $\tilde{i}$ & $\begin{array}{l}7 \\
i \\
i\end{array}$ & 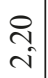 & $\hat{\sigma}$ & $\begin{array}{l}\infty \\
+ \\
0 \\
0\end{array}$ & $\begin{array}{l}\tilde{\Omega} \\
\tilde{0}\end{array}$ & $\begin{array}{c}\infty \\
\stackrel{\infty}{+} \\
\infty\end{array}$ & $\begin{array}{l}8 \\
0\end{array}$ & 8 & 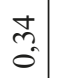 & $\begin{array}{l}n \\
\infty \\
-1\end{array}$ & $\begin{array}{l} \pm \\
\mathrm{i}\end{array}$ & $\begin{array}{l}\overrightarrow{0} \\
i\end{array}$ & $\begin{array}{l}\tilde{n} \\
\text { రీ }\end{array}$ \\
\hline & 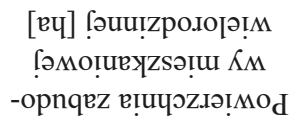 & ले & o. & $\begin{array}{l}\tilde{n} \\
\tilde{0}\end{array}$ & 8 & $\begin{array}{l}8 \\
0 \\
0\end{array}$ & $\begin{array}{l}8 \\
0 \\
0\end{array}$ & $\overrightarrow{0}$ & $\begin{array}{l}8 \\
0 \\
0\end{array}$ & $\begin{array}{l}8 \\
0 \\
0\end{array}$ & 8 & $\begin{array}{l}0 \\
0 \\
0\end{array}$ & $\mid \begin{array}{c}0 \\
2 \\
0 \\
0\end{array}$ & $\frac{m}{0}$ & 告 \\
\hline & 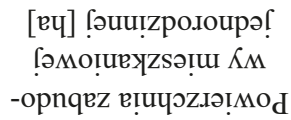 & $\stackrel{+}{\infty}$ & $\begin{array}{l}n \\
\tilde{n} \\
i\end{array}$ & $\hat{\sigma}$ & $\hat{\sigma}$ & $\begin{array}{l}\infty \\
+ \\
0 \\
0\end{array}$ & $\begin{array}{l}\tilde{I} \\
\tilde{0}\end{array}$ & $\stackrel{尺}{i}$ & $\begin{array}{l}8 \\
0 \\
0\end{array}$ & $\begin{array}{l}8 \\
0 \\
0\end{array}$ & $\begin{array}{l}+ \\
\text { ?. } \\
0\end{array}$ & $\begin{array}{l}\infty \\
-\infty \\
-1\end{array}$ & $\stackrel{\infty}{\stackrel{\infty}{\approx}}$ & $\begin{array}{l}\infty \\
\infty \\
-1\end{array}$ & $\begin{array}{l}8 \\
\infty \\
n\end{array}$ \\
\hline \multirow{3}{*}{$\begin{array}{l}\frac{\pi}{\tilde{z}} \\
\frac{\pi}{y} \\
\end{array}$} &  & $\tilde{\sim}$ & $\stackrel{?}{\stackrel{F}{i}}$ & $\begin{array}{l}\text { ì } \\
\text { i }\end{array}$ & $\vec{\sigma}$ & $\begin{array}{l}\hat{f} \\
0 \\
0\end{array}$ & $\begin{array}{l}\infty \\
\sim \\
0 \\
0\end{array}$ & $\begin{array}{l}n \\
\infty \\
\infty\end{array}$ & $\begin{array}{l}n \\
0 \\
0\end{array}$ & $\begin{array}{l}n \\
\tilde{c} \\
i\end{array}$ & $\begin{array}{l}0 \\
i \\
i\end{array}$ & $\begin{array}{l}8 \\
i \\
i\end{array} \mid$ & $\begin{array}{l}2 \\
\hat{\sigma}\end{array}$ & $\begin{array}{l}n \\
\tilde{n} \\
0\end{array}$ & $\underset{\infty}{\forall}$ \\
\hline & 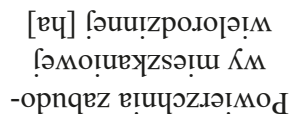 & సे & a. & $\begin{array}{l}\tilde{n} \\
\hat{0}\end{array}$ & $\begin{array}{l}8 \\
0 \\
0\end{array}$ & $\begin{array}{l}8 \\
0 \\
0\end{array}$ & $\begin{array}{l}8 \\
0\end{array}$ & $\overrightarrow{0}$ & $\begin{array}{l}8 \\
0 \\
0\end{array}$ & $\begin{array}{c}n \\
2 \\
0\end{array}$ & $\stackrel{7}{0}$ & $\begin{array}{l}\hat{n} \\
\hat{0}\end{array}$ & $\begin{array}{l}8 \\
0 \\
0\end{array}$ & $\begin{array}{l}8 \\
0 \\
0\end{array}$ & $\tilde{0}$ \\
\hline &  & $\infty$ & 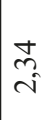 & $\hat{\sigma}_{-}$ & $\bar{\sigma}$ & $\begin{array}{l}\tilde{f} \\
0\end{array}$ & $\mid \begin{array}{l}\infty \\
\sim \\
0 \\
0\end{array}$ & $\begin{array}{l}b \\
\infty \\
\sim \\
\sim\end{array}$ & $\left|\begin{array}{l}n \\
0 \\
0\end{array}\right|$ & $\begin{array}{l}8 \\
8 \\
i\end{array}$ & $\begin{array}{c}\hat{n} \\
i\end{array}$ & $\approx$ & $\begin{array}{l}2 \\
\hat{\sigma}\end{array}$ & $\begin{array}{l}n \\
n \\
0 \\
0\end{array}$ & $\stackrel{m}{\pi}$ \\
\hline & 证 寻 & n & $\frac{0}{1}$ & $\begin{array}{l}n \\
1 \\
0 \\
-\end{array}$ & 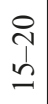 & in & $\begin{array}{l}0 \\
\tilde{n} \\
1 \\
2\end{array}$ & $\nabla$ & $\begin{array}{l}n \\
0\end{array}$ & 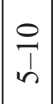 & $\begin{array}{l}n \\
1 \\
0\end{array}$ &  & 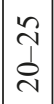 & $\begin{array}{l}\text { in } \\
i \\
i\end{array}$ & \multirow[b]{2}{*}{$\stackrel{\Xi}{\Xi}$} \\
\hline & 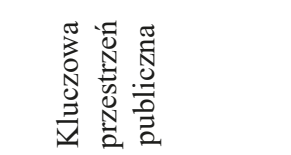 & \multicolumn{6}{|c|}{  } & ڤ̆ & \multicolumn{6}{|c|}{$\begin{array}{l}\text { पू } \\
\text { I্ } \\
\text { N }\end{array}$} & \\
\hline
\end{tabular}




\begin{tabular}{|c|c|c|c|c|c|c|c|c|c|}
\hline \multirow{3}{*}{ 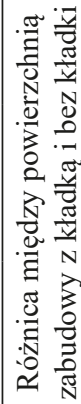 } & $\underset{\Xi}{\Xi}$ & 三 & $\begin{array}{c}\stackrel{a}{+} \\
\stackrel{f}{+}\end{array}$ & $\underset{\stackrel{\sim}{\mathcal{F}}}{\stackrel{f}{+}}$ & $\begin{array}{l}n \\
0 \\
i\end{array}$ & $\stackrel{\text { ते }}{\rightarrow}$ & $\stackrel{\substack{7 \\
i}}{i}$ & के & $\begin{array}{l}n \\
\tilde{m} \\
f\end{array}$ \\
\hline & 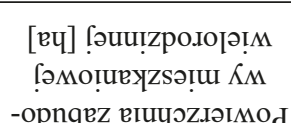 & 8 & $\begin{array}{l}\mathcal{Y} \\
\stackrel{+}{+} \\
+\end{array}$ & $\begin{array}{l}0 \\
0 \\
0 \\
+\end{array}$ & $\begin{array}{l}\tilde{0} \\
0 \\
0 \\
+\end{array}$ & $\begin{array}{l}\tilde{2} \\
\hat{n} \\
i \\
1\end{array}$ & \begin{tabular}{l}
$\infty$ \\
\multirow{1}{1}{} \\
$\hat{1}$ \\
1
\end{tabular} & 8 & $\frac{\infty}{0}$ \\
\hline & 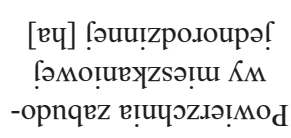 & $\begin{array}{l}= \\
0 \\
+\end{array}$ & $\begin{array}{l}\infty \\
0 \\
i \\
+\end{array}$ & 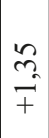 & $\begin{array}{l}\infty \\
\overrightarrow{0} \\
\dot{1}\end{array}$ & $\begin{array}{c}n \\
0 \\
-1\end{array}$ & $\begin{array}{l}0 \\
\circ \\
0 \\
1\end{array}$ & $\stackrel{m}{\stackrel{m}{f}}$ & m \\
\hline \multirow{3}{*}{$\begin{array}{l}\frac{\pi}{\bar{n}} \\
\frac{\pi}{\bar{y}} \\
N \\
0 \\
0\end{array}$} & 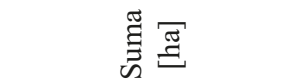 & $\begin{array}{l}8 \\
0\end{array}$ & $\frac{1}{0}$ & $\stackrel{2}{0}$ & $\begin{array}{l}\infty \\
0 \\
i\end{array}$ & $\begin{array}{l}\stackrel{2}{1} \\
i \\
c\end{array}$ & $\stackrel{\infty}{-}$ & in & ป \\
\hline & 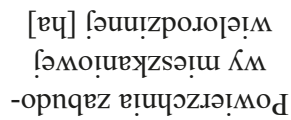 & $\begin{array}{l}8 \\
0\end{array}$ & $\begin{array}{l}8 \\
0\end{array}$ & 8 & $\begin{array}{l}\text { กิ } \\
\text { o. }\end{array}$ & $\begin{array}{l}\dddot{2} \\
\tilde{o}\end{array}$ & $\begin{array}{l}\infty \\
\text { ஸ̂ } \\
0\end{array}$ & $\frac{m}{0}$ & $\stackrel{\sigma}{\approx}$ \\
\hline & 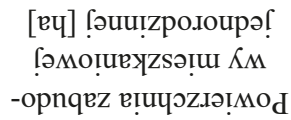 & $\begin{array}{l}8 \\
0\end{array}$ & $\begin{array}{l}\mathfrak{I} \\
0\end{array}$ & $\underset{0}{2}$ & $\begin{array}{l}\infty \\
\infty \\
-\end{array}$ & $\begin{array}{l}8 \\
i\end{array}$ & $\stackrel{n}{n}$ & ñ & 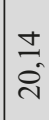 \\
\hline \multirow{3}{*}{$\begin{array}{l}\frac{\pi}{0} \\
\frac{\pi}{ \pm} \\
N\end{array}$} & 冚 & $\overline{0}$ & $\begin{array}{l}\vec{b} \\
i\end{array}$ & $\begin{array}{l}\text { f } \\
i\end{array}$ & $\tilde{\sigma}$ & $\begin{array}{l}2 \\
0 \\
0\end{array}$ & $\begin{array}{l}0 \\
n \\
0\end{array}$ & $\begin{array}{l}t \\
\infty \\
\infty\end{array}$ & $\begin{array}{l}6 \\
2 \\
2\end{array}$ \\
\hline & 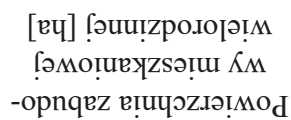 & $\begin{array}{l}8 \\
0\end{array}$ & 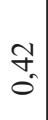 & $\begin{array}{l}1 \\
0 \\
0\end{array}$ & $\begin{array}{l}\tilde{n} \\
\hat{0}\end{array}$ & $\begin{array}{l}\tau \\
\delta \\
0\end{array}$ & 8 & $\frac{n}{0}$ & $\begin{array}{l}0 \\
\text { a }\end{array}$ \\
\hline & 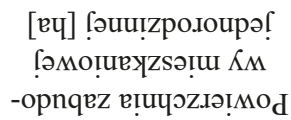 & $=$ & $\begin{array}{l}a \\
\therefore\end{array}$ & $\begin{array}{l}0 \\
+ \\
i\end{array}$ & $\stackrel{R}{=}$ & $\stackrel{n}{\sigma}$ & $\begin{array}{l}0 \\
2 \\
0 \\
0\end{array}$ & 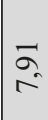 & $\begin{array}{l}\hat{q} \\
\hat{v}\end{array}$ \\
\hline & Uี & in & $\begin{array}{l}0 \\
i \\
\text { in }\end{array}$ & $\frac{n}{1}$ & 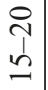 &  & $\begin{array}{l}\text { O } \\
i \\
i\end{array}$ & \multirow[b]{2}{*}{$\underset{\tilde{a}}{\vec{\Xi}}$} & $\sigma$ \\
\hline & 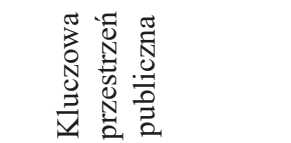 & \multicolumn{6}{|c|}{ 总 } & & 竺 \\
\hline
\end{tabular}


A
C
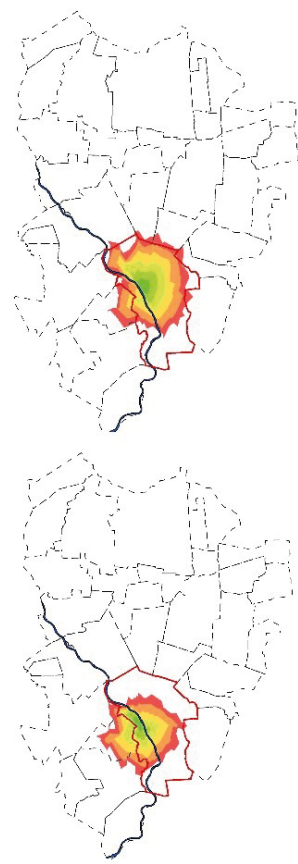

B
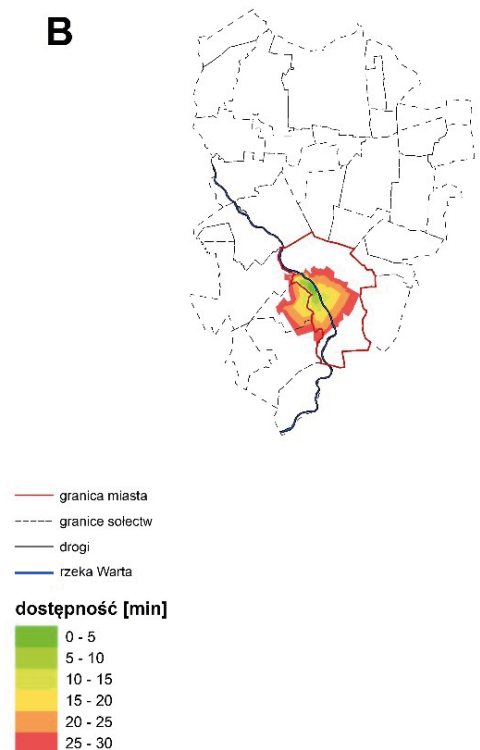

Ryc. 3. Czas dojścia pieszego [min] drogą inną niż kładka piesza do:

A. Starego Rynku, B. zamku, C. Term Uniejów Źródło: opracowanie własne na podstawie OSM, 2020

\section{B. Zamek Arcybiskupów Gnieźnieńskich}

Zamek Arcybiskupów Gnieźnieńskich to obiekt znajdujący się w Uniejowie na lewym brzegu Warty (ryc. 1). W świetle przeprowadzonego badania stwierdzono, że powierzchnia izochron dojścia pieszego do tej przestrzeni publicznej wynosi 971 ha. W ich obrębie znajdują się 893 budynki mieszkalne (z tego 871 budynków mieszkalnych jednorodzinnych i 22 wielorodzinne), w sytuacji gdy na Warcie jest kładka (ryc. 2). Największa liczba zabudowy mieszkaniowej jednorodzinnej znajduje się w obrębie izochrony 10-15 minut dojścia pieszego do zamku, gdzie jej powierzchnia wynosi 2,37 ha. Natomiast w przypadku zabudowy mieszkaniowej wielorodzinnej ich największa powierzchnia, wynosząca 0,35 ha, została odnotowana w izochronie dojścia pieszego 5-10 minut do zamku (tab. 1). Gdyby na Warcie nie było kładki, powierzchnia izochron znacznie zmniejszyłaby się, wynosząc 649 ha (ryc. 3). Tym samym łączna liczba budynków mieszkaniowych w przyjętych przedziałach czasowych wynosiłaby 698 (671 budynków mieszkaniowych jednorodzinnych, a 27 wielorodzinnych). W przypadku wyznaczonych stref, największy odsetek 
(33\%) zabudowy jednorodzinnej stanowiłyby budynki położone w izochronie dojścia pieszego 25-30 minut do zamku. W przypadku zabudowy wielorodzinnej największy udział (52\%) stanowiłyby obiekty znajdujące się w odległości 20-25 minut dojścia pieszego do opisywanej przestrzeni publicznej. W odniesieniu do analizowanego obszaru przy założeniu, że na Warcie znajduje się kładka, czas dojścia pieszego od zamku do Starego Rynku mieści się w przedziale od 5 do 10 minut, natomiast w gdyby obiekt ten nie funkcjonował, to droga zajmowałaby od 15 do 20 minut. W przypadku term czas dojścia nie uległby zmianie wynosiłby do 5 minut. Wynika to z położenia zarówno term, jak i zamku po tej samej stronie Warty.

\section{Termy}

Obiekt Termy Uniejów, będący trzecim elementem kluczowej przestrzeni publicznej w Uniejowie, znajduje się na lewym brzegu Warty. Jest to najbardziej na południe zlokalizowana przestrzeń publiczna w porównaniu z wcześniej opisanymi obszarami (ryc. 1). Badania wykazały, że wyznaczone strefy dojścia pieszego do term, przy istnieniu kładki, zajmują 1084 ha (ryc. 2), w których znajduje się 914 budynków mieszkalnych ( 891 budynków jednorodzinnych i 23 wielorodzinne). Najwięcej domów jednorodzinnych (32\%) jest zlokalizowanych w strefie dojścia pieszego 10-15 minut od term, wielorodzinnych (65\%) natomiast w izochronie 5-10 min. W sytuacji gdyby kładka zostala usunięta, powierzchnia izochron na analizowanym obszarze byłaby znacznie mniejsza i wynosiłaby 787 ha (ryc. 3). W analizowanych strefach znajdowałoby się 759 budynków mieszkalnych jednorodzinnych o łącznej powierzchni 6,57 ha, których największy udział (32\%) przypadałby na strefę dojścia od 20 do 25 minut. W przypadku zabudowy wielorodzinnej, która zajmuje 0,73 ha (tab. 1), największy odsetek zabudowy (48\%) zlokalizowany jest $\mathrm{w}$ izochronie dojścia pieszego $15-20 \mathrm{~min}$. Zestawiając ze sobą wskazane przestrzenie publiczne, w odniesieniu do lokalizacji term, różnice w czasie dojścia są zauważalne tylko w przypadku Starego Rynku. Przy założeniu, że na badanym obszarze znajduje się kładka piesza, położony jest on w strefie do 5 min dojścia pieszego od term. Jednak gdyby na Warcie nie było kładki, miejsca te oddalone byłyby od siebie o 15-20 min dojścia pieszego. $Z$ kolei w przypadku dojścia pieszego $\mathrm{z}$ term do zamku istnienie kładki nie ma znaczenia ze względu na ich położenie po tej samej, lewej stronie rzeki.

\section{Dostępność piesza - analiza porównawcza}

Powyższe badania wykazały, że w przypadku dostępności pieszej kluczowych przestrzeni publicznych, przy funkcjonowaniu kładki na Warcie w Uniejowie, izochrony w zasadzie się na siebie nakładają (przede wszystkim w odniesieniu do Zamku Arcybiskupów Gnieźnieńskich i term), przybierając niemal koncentryczny charakter. Najbardziej korzystny czas dojścia pieszego mają mieszkańcy zabudowy jednorodzinnej, znajdującej się na prawym brzegu rzeki, niemal na- 
przeciwko term i zamku. Obszar ten to teren średniowiecznego miasta lokacyjnego wraz z rynkiem ${ }^{32}$. Stary Rynek odznacza się natomiast lepszą dostępnością, w porównaniu z dwiema omówionymi wcześniej przestrzeniami publicznymi, dla mieszkańców zabudowy mieszkalnej położonej na północy miasta, na prawym brzegu rzeki (ryc. 2).

Przy założeniu, że na Warcie nie funkcjonuje kładka, izochrony przybierają różne, zdecydowanie nieregularne kształty. Zajmują one także mniejszą powierzchnię niż w pierwszym przypadku. W odniesieniu do Zamku Arcybiskupów Gnieźnieńskich czas dojścia pieszego jest najkrótszy dla mieszkańców, których domy położone są po prawej stronie Warty, na południe od niego. Teren ten obejmuje obszar dawnej osady targowej, czyli miasta przedlokacyjnego ${ }^{33}$. Trzeba przy zaznaczyć, że chociaż mieszkańcy Ci w porównaniu z pozostałymi mają najlepszy dostęp do zamku, to czas ich dojścia mieści się w przedziale od 10 do 15 min. W przypadku term sytuacja wygląda niemal identycznie, jednakże obszar tej zabudowy mieszkaniowej mieści się w strefie od 5 do $10 \mathrm{~min}$, a różnica ta wynika $\mathrm{z}$ położenia term $\mathrm{w}$ kierunku południowym $\mathrm{w}$ stosunku do zamku. $\mathrm{W}$ odniesieniu do Starego Rynku nie zmieni się dostępność dla większości mieszkańców miasta, które rozwinęło się właśnie na prawym brzegu, ale pogorszy się powiązanie pomiędzy poszczególnymi przestrzeniami publicznymi (ryc. 3).

\section{DOSTĘPNOŚĆ ROWEREM}

\section{A. Stary Rynek}

Izochrony dojazdu rowerem do Starego Rynku w przypadku występowania kładki zajmują łącznie 7597 ha (ryc. 4), a więc stanowią 58\% powierzchni gminy Uniejów. Na badanym obszarze łącznie występuje 1814 budynków mieszkalnych, z czego 1789 to obiekty jednorodzinne, a 25 wielorodzinne. Największy udział zabudowy jednorodzinnej, jak i wielorodzinnej (wynoszący odpowiednio 36\% i $80 \%$ ogółu poszczególnych budynków) występuje w bezpośrednim sąsiedztwie Starego Rynku, do 5 minut dojazdu rowerem. W przypadku gdyby na Warcie nie funkcjonowała kładka, obszar zajęty przez wyznaczone strefy byłby mniejszy i wynosiłby 6852 ha (ryc. 5), a więc obejmowałby zasięgiem 53\% powierzchni gminy. Budynki mieszkalne jednorodzinne zlokalizowane w zasięgu przyjętych stref to 1713 obiektów. Największy w nich udział (39\%) stanowią te, z których czas dojazdu rowerem do Starego Rynku wynosi do 5 min (tab. 2). Liczba budynków wielorodzinnych, w tym przypadku to 24 , z których również największy odsetek stanowią obiekty w zasięgu izochrony od 0 do 5 min dojazdu rowerem do omawianego obszaru.

\footnotetext{
${ }_{32}$ M. Lamprecht, Kilka uwag o rozwoju Uniejowa..., s. 131.

33 Tamże.
} 


\section{B. Zamek Arcybiskupów Gnieźnieńskich}

Z przeprowadzonego badania wynika, że obszar zajęty przez izochrony dojazdu rowerem do Zamku Arcybiskupów Gnieźnieńskich w przypadku możliwości przejazdu przez kładkę pieszą to 7440 ha (ryc. 4), a więc pokrywają one $57 \%$ gminy. Łączna liczba budynków mieszkalnych na badanym obszarze to 1746, z czego 1721 to obiekty jednorodzinne, a 25 wielorodzinne. Wśród zabudowy jednorodzinnej, jak i wielorodzinnej największy udział (odpowiednio: $26 \%$ i $60 \%$ ) stanowią zabudowania mieszkaniowe zlokalizowane w izochronie do 5 min dojazdu rowerem do omawianej przestrzeni publicznej. W przypadku braku kładki na Warcie powierzchnia wyznaczonych stref wynosiłaby 7234 ha (ryc. 5), co stanowi 56\% powierzchni gminy Uniejów.

A



C

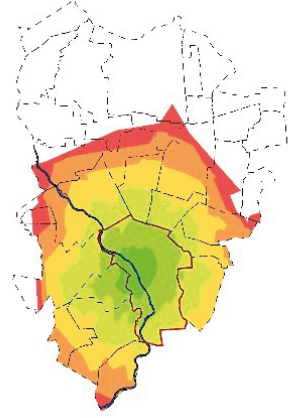

B

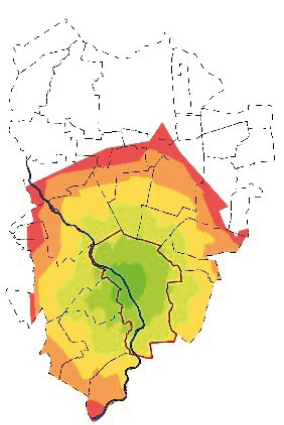

Ryc. 4. Czas dojazdu rowerem [min] (przez kładkę pieszą) do:

A. Starego Rynku, B. zamku, C. term w Uniejowie Źródło: opracowanie własne na podstawie OSM, 2020 
W przypadku budynków mieszkalnych ich łączna liczba w zasięgu wyznaczonych stref wynosiłaby 1661, z czego 1637 stanowiłyby budynki jednorodzinne, a 24 wielorodzinne, zajmując odpowiednio 15,48 ha i 0,82 ha (tab. 2). W tej sytuacji znacząco zmienia się liczba budynków w poszczególnych izochronach, zwłaszcza w przypadku zabudowy jednorodzinnej, której największy odsetek (36\%) stanowiłyby budynki znajdujące się w izochronie od 5 do 10 min dojazdu rowerem do zamku. Podobnie sytuacja zmieniłaby się w odniesieniu do zabudowy wielorodzinnej, której w ogóle nie byłoby w strefie do 5 minut dojazdu rowerem, natomiast największy odsetek stanowiłyby $(80 \%)$ budynki znajdujące się w odległości od 5 do 10 minut od zamku.

A

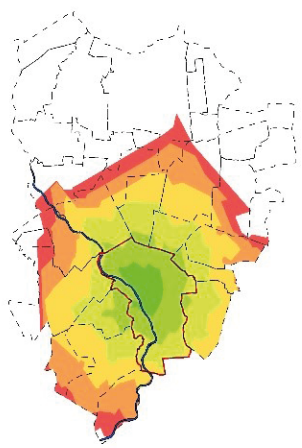

C

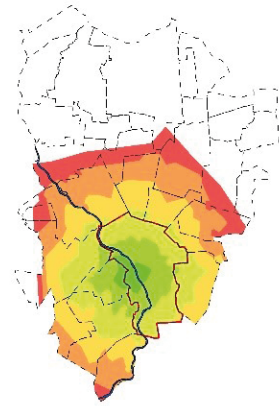

B
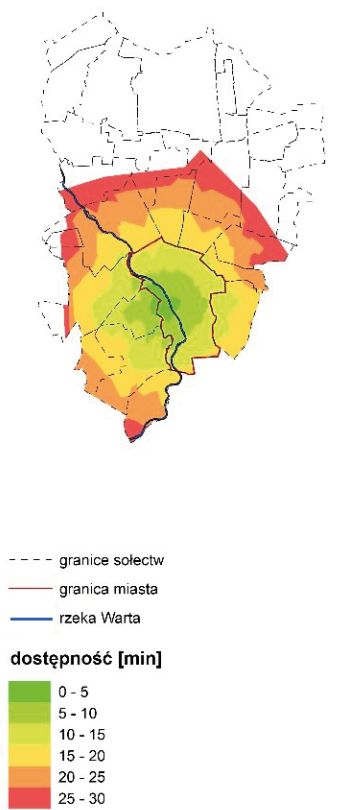

Ryc. 5. Czas dojazdu rowerem [min] (drogą inną niż kładka) do:

A. Starego Rynku, B. zamku, C. term w Uniejowie Źródło: opracowanie własne na podstawie OSM, 2020 


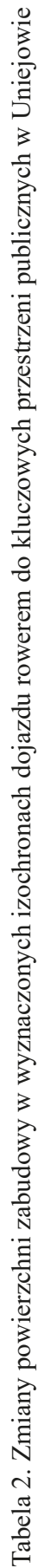

\begin{tabular}{|c|c|c|c|c|c|c|c|c|c|c|c|c|c|c|c|}
\hline \multirow{3}{*}{ 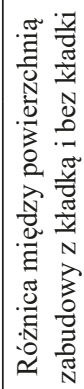 } &  & $\begin{array}{l}1 \\
0 \\
0 \\
+\end{array}$ & $\begin{array}{l}n \\
0 \\
0 \\
1\end{array}$ & $\begin{array}{l}n \\
\tilde{o} \\
+\end{array}$ & $\begin{array}{l}0 \\
+ \\
+ \\
i \\
1\end{array}$ & $\begin{array}{l}\tilde{n} \\
\tilde{o} \\
+\end{array}$ & $\begin{array}{l}\tilde{N} \\
\tilde{+} \\
+\end{array}$ & $\begin{array}{l}\tilde{2} \\
\infty \\
\dot{+}\end{array}$ & $\begin{array}{l}0 \\
0 \\
+ \\
+\end{array}$ & $\begin{array}{c}\hat{n} \\
\hat{1}\end{array}$ & $\left|\begin{array}{l}n \\
\infty \\
0 \\
1\end{array}\right|$ & $\begin{array}{l}\hat{\sigma} \\
\hat{o} \\
+\end{array}$ & $\frac{+}{i}$ & \begin{tabular}{l}
$\infty$ \\
\multirow{1}{0}{} \\
0 \\
+
\end{tabular} & $\stackrel{n}{\mathfrak{n}}$ \\
\hline & 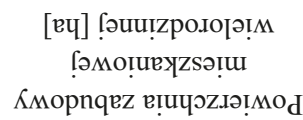 & 8 & 8 & $\begin{array}{l}8 \\
8\end{array}$ & $\begin{array}{l}8 \\
0 \\
0\end{array}$ & $\begin{array}{l}8 \\
0 \\
0\end{array}$ & $\begin{array}{l}8 \\
0 \\
0\end{array} \mid$ & 8 & $\begin{array}{l}a \\
\mathfrak{q} \\
\hat{o} \\
+\end{array}$ & $\begin{array}{l}n \\
q \\
0 \\
1 \\
1\end{array}$ & $\mid \begin{array}{l}0 \\
0 \\
0 \\
1\end{array}$ & $\begin{array}{l}8 \\
0^{\prime}\end{array}$ & $\begin{array}{l}0 \\
0 \\
0 \\
+\end{array}$ & $\begin{array}{l}0 \\
0 \\
0 \\
1\end{array}$ & 8 \\
\hline & 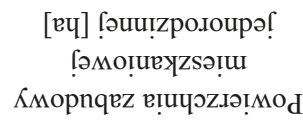 & $\begin{array}{l}5 \\
0 \\
0\end{array}$ & $\begin{array}{l}n \\
0 \\
0 \\
0\end{array}$ & $\begin{array}{l}n \\
\tilde{o}\end{array}$ & $\begin{array}{l}0 \\
+ \\
0 \\
0 \\
1\end{array}$ & $\begin{array}{l}n \\
2 \\
0 \\
+\end{array}$ & $\mid \begin{array}{l}\tilde{N} \\
\tilde{+} \\
\uparrow\end{array}$ & $\begin{array}{l}\tilde{\omega} \\
0 \\
+\end{array}$ & $\begin{array}{l} \pm \\
\dot{+} \\
+\end{array}$ & $\left|\begin{array}{l}\infty \\
n \\
i \\
i\end{array}\right|$ & $\mid \begin{array}{c}-\infty \\
0 \\
i \\
1\end{array}$ & $\left|\begin{array}{l}\hat{\sigma} \\
\hat{\alpha}\end{array}\right|$ & $\hat{\hat{n}}$ & $\begin{array}{c}1 \\
2 \\
0 \\
+ \\
+\end{array}$ & $\stackrel{2}{7}$ \\
\hline \multirow{3}{*}{ 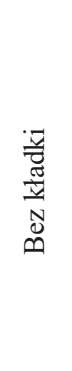 } & 恚 丞 & o & $\stackrel{\tilde{f}}{-}$ & $\begin{array}{l}R \\
m\end{array}$ & $\begin{array}{l}\text { To } \\
i\end{array}$ & $\stackrel{\sim}{\sim}$ & $\begin{array}{l}2 \\
\hat{\sigma}\end{array}$ & $\begin{array}{l}= \\
=\end{array}$ & 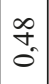 & $\begin{array}{l}\text { J } \\
\text { ó }\end{array}$ & $\left|\begin{array}{c}\tilde{\delta} \\
\dot{\gamma}\end{array}\right|$ & $\begin{array}{c}0 \\
i \\
i\end{array}$ & $\frac{\infty}{i}$ & $\cong$ & $\begin{array}{l}\bar{n} \\
0\end{array}$ \\
\hline & 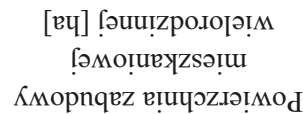 & $\underline{\nabla}$ & 8 & $\begin{array}{l}2 \\
0 \\
0\end{array}$ & $\begin{array}{l}+ \\
0 \\
0\end{array}$ & $\begin{array}{l}\overrightarrow{0} \\
0\end{array}$ & $\begin{array}{l}8 \\
0 \\
0\end{array} \mid$ & $\begin{array}{c}1 \\
\infty \\
0\end{array}$ & 8 & $\mid \begin{array}{l}\infty \\
0 \\
0 \\
0\end{array}$ & $\begin{array}{l}0 \\
0 \\
0\end{array}$ & $\begin{array}{l}1 \\
\delta \\
0\end{array}$ & 8 & $\begin{array}{l} \pm \\
0 \\
0\end{array}$ & $\begin{array}{l}\text { D } \\
\infty \\
0\end{array}$ \\
\hline & 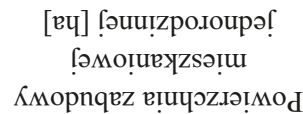 & $\begin{array}{l}\infty \\
\text { nె. }\end{array}$ & $\tilde{f}_{-}$ & $\begin{array}{c}\mathbb{J} \\
\text { ๙ }\end{array}$ & $\begin{array}{l}\infty \\
n \\
i\end{array}$ & $\stackrel{\overbrace{}}{\simeq}$ & $\begin{array}{l}\hat{\sigma} \\
\hat{\sigma}\end{array}$ & $\begin{array}{l}\text { సे } \\
\text { ठ́ }\end{array}$ & 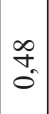 & $\begin{array}{l}0 \\
\therefore \\
n\end{array}$ & $\begin{array}{c}\tilde{\gamma} \\
\hat{n}\end{array} \mid$ & $\left|\begin{array}{l}\infty \\
0 \\
i \\
i\end{array}\right|$ & $\frac{\infty}{\vec{c}}$ & $\stackrel{0}{0}$ & $\begin{array}{l}\stackrel{\infty}{+} \\
\stackrel{n}{n}\end{array}$ \\
\hline \multirow{3}{*}{$\begin{array}{l}\frac{\pi}{\tilde{y}} \\
\frac{\pi}{ \pm} \\
N\end{array}$} & 㲎 & $\frac{0}{1}$ & $\stackrel{\sim}{\stackrel{\sim}{\sim}}$ & $\begin{array}{l}\tilde{\sigma} \\
\tilde{\sigma}\end{array}$ & $\vec{i}$ & $\stackrel{0}{2}$ & $\vec{\sim}$ & $\begin{array}{l}\Xi \\
\text { İ }\end{array}$ & $\underset{\sim}{ \pm}$ & $\begin{array}{c}o \\
q \\
m\end{array}$ & $\frac{\Xi}{m}$ & $\begin{array}{c}\tilde{\sigma} \\
\tilde{n} \\
\tilde{n}\end{array}$ & $\underset{\sim}{\stackrel{*}{*}}$ & $\begin{array}{l}\infty \\
m \\
-\end{array}$ & $\begin{array}{l}n \\
n \\
=\end{array}$ \\
\hline & 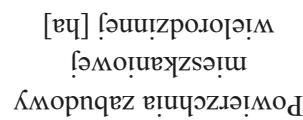 & $\bar{\sigma}$ & 8 & $\begin{array}{l}2 \\
0 \\
0\end{array}$ & $\begin{array}{l}+ \\
0 \\
0\end{array}$ & $\begin{array}{l}\overline{0} \\
0\end{array}$ & $\begin{array}{l}8 \\
0\end{array}$ & $\begin{array}{l}1 \\
\infty \\
0\end{array}$ & $\stackrel{\substack{a \\
\hdashline}}{0}$ & $\begin{array}{c}\tilde{1} \\
\tilde{0}\end{array}$ & $\begin{array}{l}n \\
0 \\
0\end{array} \mid$ & $\begin{array}{l}\sigma \\
\delta \\
0\end{array}$ & $\mathbb{O}_{0}$ & 8 & $\begin{array}{l}\sigma^{2} \\
0 \\
0\end{array}$ \\
\hline & 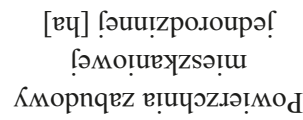 & 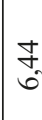 & $\stackrel{\mathcal{I}}{\rightarrow}$ & $\stackrel{\infty}{\underset{f}{f}}$ & $\stackrel{\vec{c}}{\stackrel{a}{0}}$ & $\stackrel{+}{\stackrel{\sim}{=}}$ & $\overrightarrow{\widetilde{N}}$ & $\begin{array}{l}= \\
\Xi\end{array}$ & $\begin{array}{l}n \\
\tilde{\sigma} \\
+\end{array}$ & $\frac{\infty}{\vec{n}}$ & $\frac{\sim}{m}$ & \begin{tabular}{|c}
$\vec{\sigma}$ \\
$\dot{n}$
\end{tabular} \mid & $\stackrel{q}{q}$ & $\begin{array}{l}\infty \\
\mathfrak{n} \\
-\end{array}$ & $\stackrel{2}{0}$ \\
\hline & 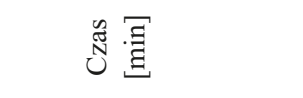 & in & $\frac{0}{1}$ & $\frac{n}{d}$ & $\begin{array}{l}\stackrel{\sim}{1} \\
\stackrel{n}{2}\end{array}$ & în & $\begin{array}{l}0 \\
i \\
1 \\
\end{array}$ & \multirow{2}{*}{ 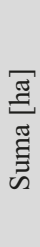 } & $n$ & 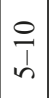 & $\begin{array}{l}n \\
0 \\
0\end{array}$ & 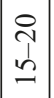 & $\stackrel{\sim}{\tilde{N}}$ & $\begin{array}{l}0 \\
i \\
1 \\
n\end{array}$ & \multirow{2}{*}{ 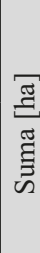 } \\
\hline & 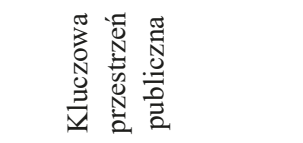 & \multicolumn{6}{|c|}{ 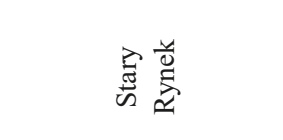 } & & \multicolumn{6}{|c|}{  } & \\
\hline
\end{tabular}




\begin{tabular}{|c|c|c|c|c|c|c|c|c|c|}
\hline 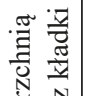 & 壹 & $\begin{array}{c}\hat{\sigma} \\
\hat{+}\end{array}$ & $\begin{array}{c}\hat{0} \\
\hat{r} \\
1\end{array}$ & $\begin{array}{l}0 \\
\stackrel{1}{1} \\
0\end{array}$ & $\begin{array}{l}\stackrel{0}{+} \\
\stackrel{+}{+} \\
+\end{array}$ & \begin{tabular}{l}
0 \\
\multirow{1}{1}{} \\
0 \\
1
\end{tabular} & $\stackrel{-}{a}$ & $\begin{array}{l}\exists \\
\mp\end{array}$ & $\stackrel{\infty}{m}$ \\
\hline 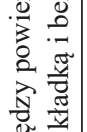 & 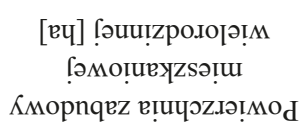 & 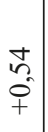 & $\begin{array}{l}0 \\
n \\
0 \\
i \\
1\end{array}$ & $\begin{array}{l}8 \\
8 \\
0\end{array}$ & $\begin{array}{l}1 \\
\delta \\
0 \\
+\end{array}$ & $\begin{array}{l}8 \\
0 \\
0\end{array}$ & $\begin{array}{l}\overrightarrow{0} \\
0 \\
0 \\
1\end{array}$ & 8 & 8 \\
\hline 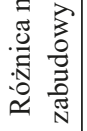 & 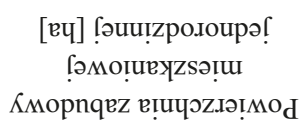 & $\begin{array}{l}\stackrel{q}{f} \\
\stackrel{f}{f}\end{array}$ & $\begin{array}{l}n \\
n \\
i \\
i\end{array} \mid$ & $\begin{array}{l}0 \\
\stackrel{0}{0} \\
1\end{array}$ & $\begin{array}{l}\infty \\
2 \\
\vdots \\
+\end{array}$ & $\mid \begin{array}{l}2 \\
1 \\
0 \\
1 \\
1\end{array}$ & $\stackrel{\infty}{\infty}$ & $\begin{array}{l}= \\
\overline{+}\end{array}$ & $\frac{\infty}{m}$ \\
\hline \multirow{3}{*}{ 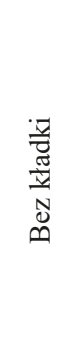 } & $\underset{\tilde{E}}{\stackrel{\Xi}{\Xi}}$ & $\vec{n}$ & $\mid$ & $\begin{array}{l}n \\
m \\
m\end{array}$ & $\hat{n}$ & $\stackrel{\infty}{\stackrel{\infty}{=}}$ & $\stackrel{\vartheta}{-}$ & $\begin{array}{l}8 \\
0 \\
0\end{array}$ & $\begin{array}{l}\text { 2. } \\
\delta \\
0 \\
n\end{array}$ \\
\hline & 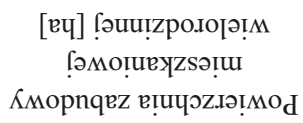 & $\begin{array}{l}8 \\
0\end{array}$ & $\hat{a}$ & $\begin{array}{l}8 \\
0\end{array}$ & 8 & $\begin{array}{l}0 \\
0 \\
0\end{array}$ & $\tilde{0}$ & $\begin{array}{l}1 \\
0 \\
0 \\
0\end{array}$ & 宇 \\
\hline & 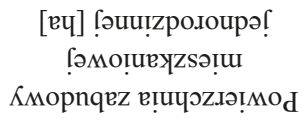 & $\vec{n}$ & $\begin{array}{c}8 \\
0 \\
n\end{array}$ & $\begin{array}{l}m \\
m \\
m \\
m\end{array}$ & $\begin{array}{c}\hat{m} \\
i \\
i\end{array}$ & $\stackrel{ \pm}{\beth}$ & $\vec{\sim}$ & $\stackrel{\infty}{\infty}$ & $\begin{array}{l}n \\
\tilde{z} \\
r\end{array}$ \\
\hline \multirow{3}{*}{ 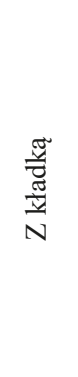 } & 䄈 & $\begin{array}{l}\infty \\
\stackrel{\infty}{n} \\
i\end{array}$ & ते & $\begin{array}{l}2 \\
i \\
m\end{array}$ & $\hat{i}$ & $\stackrel{n}{n}$ & 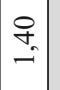 & $\stackrel{\approx}{\approx}$ & $\begin{array}{l}\text { ก } \\
\text { nn }\end{array}$ \\
\hline & 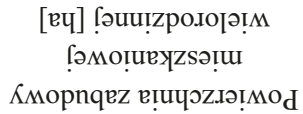 & 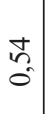 & $\begin{array}{l}\tilde{N} \\
\tilde{\sigma}\end{array}$ & $\begin{array}{l}8 \\
0\end{array}$ & $\overbrace{0}^{2}$ & $\begin{array}{l}0 \\
0 \\
0\end{array}$ & 8 & $\begin{array}{l}1 \\
\infty \\
0\end{array}$ & $\begin{array}{l}\text { f } \\
i\end{array}$ \\
\hline & 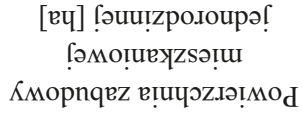 & $\begin{array}{l}\vec{\sigma} \\
\vec{\sigma}\end{array}$ & $\begin{array}{c}5 \\
\dot{n}\end{array}$ & $\begin{array}{l}\tilde{a} \\
\cdots \\
m\end{array}$ & $\begin{array}{l}n \\
i \\
i\end{array}$ & $\underset{\stackrel{q}{q}}{\stackrel{q}{q}}$ & 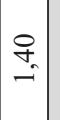 & $\begin{array}{l}2 \\
0 \\
0 \\
0\end{array}$ & $\frac{m}{\tilde{0}}$ \\
\hline & 疍 寻 & $\tilde{o}$ & $\begin{array}{l}0 \\
1 \\
n\end{array}$ & $\stackrel{n}{0}$ & 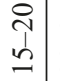 & $\begin{array}{l}n \\
\tilde{1} \\
\tilde{N}\end{array}$ & $\begin{array}{l}0 \\
i n \\
n \\
n\end{array}$ & & $\sigma$ \\
\hline & 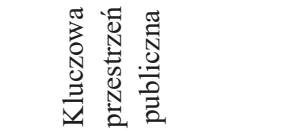 & & & & & & & 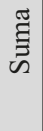 & 胥 \\
\hline
\end{tabular}




\section{Termy}

W przypadku term, gdy na Warcie funkcjonuje kładka, izochrony zajmują 7525 ha (ryc. 4), czyli 58\% powierzchni gminy. W tej sytuacji łączna liczba budynków mieszkalnych w wyznaczonych strefach to 1796, z czego 1771 stanowią obiekty jednorodzinne, a 25 wielorodzinne. W obydwu przypadkach ich największy odsetek stanowią domy, z których czas dojazdu rowerem do term nie przekracza 5 min, odpowiednio dla jedno- i wielorodzinnych wynosząc $28 \%$ i 68\%. Gdyby na rzece nie było kładki, sytuacja wyglądałaby zdecydowanie inaczej. Powierzchnia izochron dojazdu rowerem wyniosłaby 7004 ha (ryc. 5), a więc pokrywałyby one 54\% terenu gminy. Liczba budynków mieszkalnych zmniejszyłaby się do 1695 , z czego 1671 to obiekty o charakterze jednorodzinnym, a 24 to budynki wielorodzinne, zajmujące odpowiednio 16,60 i 0,82 ha. Największy odsetek stanowiłyby obiekty znajdujące się w izochronach od 5 do 10 minut dojazdu rowerem do zamku, z czego w zbiorze obiektów jednorodzinnych byłoby to $36 \%$, a w grupie wielorodzinnych $84 \%$ ogółu budynków mieszkalnych.

\section{Dostępność rowerem - analiza porównawcza}

Izochrony ukazujące czas dojazdu rowerem do poszczególnych przestrzeni publicznych w Uniejowie, w sytuacji gdy na Warcie znajduje się kładka, podobnie jak w przykładzie dotyczącym dostępności pieszej, nakładają się na siebie, szczególnie w przypadku zamku i term. Najlepszą dostępnością rowerem charakteryzują się obszary położone w centrum i na południu gminy, gdzie najdalej wysuniętym na północ osiągalnym punktem do 30 minut podróży są południowe rubieże wsi Wilamów. Najdogodniejszymi warunkami dojazdu rowerem do badanych obszarów dysponują przede wszystkim mieszkańcy miasta Uniejów oraz miejscowości położonych w jego bezpośrednim sąsiedztwie (ryc. 4). W tym przypadku nie ma żadnej różnicy w strefach, w których znajdują się poszczególne przestrzenie. Wszystkie bez wyjątku zlokalizowane są w odległości do 5 minut dojazdu.

Gdyby na Warcie w Uniejowie nie było kładki pieszej, izochrony dojazdu rowerem dla term i zamku przybierałyby podobny kształt, przy czym swym zasięgiem (do 30 min dojazdu) nie obejmowałyby tak dużego obszaru jak w przypadku istnienia obiektu mostowego na omawianej rzece (ryc. 5). W odniesieniu do zamku i term zasięg dostępności do 30 min dojazdu rowerem na północy miałby swoje granice w miejscowości Stanisławów. W przypadku Starego Rynku zasięg dostępności rowerem w kierunku północnym byłby nieco większy, docierający do wsi Wilamów. Odległości czasowe między poszczególnymi przestrzeniami publicznymi nie zmieniłyby się w tej sytuacji. 


\section{WNIOSKI}

Przestrzenie publiczne to nieodzowny element tkanki miejskiej. Ich rozwój uwarunkowany jest wieloma czynnikami, a także zależy od różnych barier (przestrzennych, architektonicznych, naturalnych). W powyższej pracy podjęto się oceny zmian dostępności pieszej i rowerem przestrzeni publicznych w Uniejowie. Zmiany te dotyczyły możliwości poruszania się pomiędzy tymi obszarami dzięki istnieniu kładki pieszej na Warcie, która dopuszcza również podróżowanie rowerem. Zmierzono je przy pomocy liczby i powierzchni zabudowy jedno- i wielorodzinnej w poszczególnych izochronach.

Dla mieszkańców północnej części miasta (na prawym brzegu Warty), w przypadku pieszego poruszania się po mieście bez kładki, droga do term i zamku wynosiłaby ponad 30 minut (wydłużyłaby się o ok. 10 minut w porównaniu do wariantu z kładką). Przeprowadzone badanie pokazuje, że przestrzenią publiczną, dla której najmniejsze znaczenie ma kładka, w kontekście przede wszystkim dostępności dla mieszkańców, jest obszar Starego Rynku, a więc teren znajdujący się po prawej stronie rzeki Warty. Jednakże patrząc na to miejsce z perspektywy turystów, którzy przyjeżdżają do Uniejowa, głównie w celu skorzystania ze strefy uzdrowiskowo-rekreacyjnej, brak kładki wydłużyłby w ich przypadku niemal trzykrotnie drogę do Starego Rynku ${ }^{34}$.

Analizując dostępność rowerem, sytuacja wygląda niemal identycznie jak w odniesieniu do analiz pieszych. Dostępność dla mieszkańców północnoi północno-zachodnich obszarów gminy spada wraz z zamknięciem kładki na Warcie. Różnica ta najwyraźniej widoczna jest w przypadku zamku, najmniej przy Starym Rynku.

Badanie zmian dostępności pieszej i rowerem, które przeprowadzono, jednoznacznie wskazuje na wagę opisywanego obiektu, jakim jest kładka piesza. Umożliwia ona swobodne poruszanie się między kluczowymi przestrzeniami publicznymi, a także stanowi o poziomie ich dostępności dla użytkowników. Kładka ta to również istotny element łączący przestrzenie publiczne z punktu widzenia turystów. Osoby odwiedzające miasto, głównie ze względu na funkcjonowanie w nim term, dzięki kładce mogą łatwiej przedostać się na prawy brzeg Warty, a tym samym odwiedzić Stary Rynek. Przeprowadzona analiza może być zatem punktem wyjścia do kolejnych badań dotyczących postrzegania kładki przez turystów. Badanie takie pozwoliłoby na sprawdzenie, czy istnienie tego obiektu ma wpływ na podjęcie decyzji dotyczącej odwiedzania obszaru Starego Rynku.

${ }^{34}$ Dystans do pokonania przez użytkowania przestrzeni, który chciałby pojawić się w każdej z omawianych przestrzeni, to dla trasy: termy - zamek - Stary Rynek z kładką 666,7 m i 1839,9 m bez kładki, natomiast trasy: zamek - termy - Stary Rynek: 1625,3 m bez kładki i 636,8 m z kładką. Obliczenia wykonano na podstawie dróg OSM w programie ArcMapy przy użyciu Network Analyst. 


\section{Bibliografia}

Borowska-Stefańska M., Wojtczak M., Dostępność piesza i transportem indywidualnym do parków w Turku i Koninie, „Biuletyn Uniejowski” 2019, t. 8, s. 161-179.

Brodowicz D., Domaradzka A., Sadowy K., Lokalność, przestrzeń publiczna, kapitat społeczny - cele, osiagnięcia $i$ wyzwania ksztaltowania przestrzeni publicznej Warszawy w odniesieniu do Spolecznej Strategii Warszawy oraz propozycje metodologii monitorowania jej realizacji. Raport, 2015, s. 22-23.

Chmielewski J.M., Przestrzeń publiczna w teorii urbniastyki, [w:] S. Gzell (red.), Przestrzeń publiczna jako element krystalizacji zespołów urbanistycznych, „Urbanistyka. Międzyuczelniane Zeszyty Naukowe" 2005, s. 5-10.

Dębowska-Mróz M., Lis P., Ksztaltowanie przestrzeni transportowej dedykowanej pieszym i rowerzystom jako element poprawy mobilności w miastach, „Autobusy: Technika, Eksploatacja, Systemy Transportowe" 2017, nr 18, s. 523.

Furtak M., Remont i częściowa odbudowa kładki pieszej przez rzekę Rabę, w perspektywie krajobrazowo-kulturowo-inżynierskiej, „Przestrzeń i Forma” 2011, nr 16, s. 577-588.

Komornicki T., Śleszyński P., Rosik P., Pomianowski W., Stępniak M., Silka P., Dostępność przestrzenna jako przestanka ksztaltowania polskiej polityki transportowej, „Biuletyn KPZK PAN" 2010, z. 241, s. 16-35.

Lamprecht M., Kilka uwag o rozwoju Uniejowa w świetle nowych funkcji miasta, „Biuletyn Uniejowski” 2012, t. 1, s. 131-139.

Lorens P., Definiowanie wspótczesnej przestrzeni publicznej, [w:] P. Lorens, J. Martyniuk-Pęczek (red.), Problemy ksztaltowania przestrzeni publicznych, „Urbanista” 2010, s. 6-18.

Nissen S., Urban Transformation from Public and Private Space to Space of Hybrid Character, „Czech Sociological Review” 2008, t. 44, nr 6, s. 1129-1149.

Ossowicz T., Przestrzenie publiczne w sferze dyskusji, Konferencja naukowa na temat przestrzeni publicznej, Poznań, 27-29.05.2009.

Rakower R., Łabędzki J., Gadziński J., Konkurencyjność ruchu rowerowego w przestrzeni miejskiej, „Transport Miejski i Regionalny” 2011, nr 2, s. 31-38.

Rochmińska A., Centra handlowe jako przestrzenie hybrydowe, „Space-Society-Economy” 2014, nr 13, s. 281- 297.

Sarga A., Wpływ kładki „Bernatka” na strukture funkcjonalno-przestrzenna krakowskiego Kazimierza i Podgórza, „Przestrzeń i Forma” 2014, nr 21, s. 473-482.

Sierpiński G., Miary dostępności transportowej miast i regionów, „Zeszyty Naukowe Politechniki Śląskiej. Transport” 2010, z. 66, s. 91-96.

Soszyński D., Sowińska-Świerkosz B., Gawryluk A., Ksztaltowanie wiejskich przestrzeni publicznych - ocena rozwiazań krajobrazowych w wybranych gminach Polesia Zachodniego, „Prace Komisji Krajobrazu Kulturowego" 2016, nr 34, s. 149-162.

Śleszyński P., Dostępność czasowa i jej zastosowania, „Przegląd Geograficzny” 2014, nr 86 (2), s. $171-215$.

Ustawa z dnia 21 marca 1985 r. o drogach publicznych (DzU 1985, poz. 60), art. 4, pkt 13.

Ustawa z dnia 27 marca 2003 r. o planowaniu i zagospodarowaniu przestrzennym (DzU 2003, poz. 717), art. 2, pkt 6 .

Wiśniewski S., Zróżnicowanie dostępności transportowej miast $w$ województwie łódzkim, Wyd. Uniwersytetu Łódzkiego, Łódź 2015. 
Wojnarowska A., Przestrzeń publiczna Uniejowa, „Biuletyn Uniejowski” 2015, t. 4, s. 25-44.

Zmiana studium uwarunkowań i kierunków zagospodarowania przestrzennego gminy $i$ miasta Uniejów, Uniejów 2007-2009.

Żółtowski K., Binczyk M., Galewski T., Lukowa kladka dla pieszych przez rzekę Warta we Wronkach: projekt i realizacja, „Mosty” 2015, s. 54-56.

\section{Źródła internetowe}

http://www.geoportal.gov.pl [dostęp: 15.04.2020].

https://mapadotacji.gov.pl/projekty/756630/ [dostęp: 3.05.2020].

\section{CHANGES IN PEDESTRIAN AND BICYCLE ACCESSIBILITY OF KEY PUBLIC SPACES IN UNIEJÓW - THE EXAMPLE OF A FOOT-BRIDGE ON THE RIVER WARTA}

\section{Summary}

The article presents an assessment of changes in accessibility of key public spaces in Uniejów, on foot and by bicycle, using as an example a foot-bridge on the river Warta. Public spaces are places that fulfil a number of functions in both the economic and the social sphere. Accessibility, which is one of their qualities, is the subject of this study. The method of isochrones was used to show changes in areas of single-family and multifamily housing in chosen time intervals. The study shows how a foot-bridge can be an important element in improving accessibility for public space users. Uniejów

Keywords: pedestrian accessibility, foot-bridge, accessibility by bicycle, key public space,

Data nadesłania artykułu: kwiecień 2020

Data akceptacji: maj 2020 